\title{
SZÁMÍTÓGÉP VEZÉRELT HŐGRADIENS RENDSZER TERVEZÉSE ÉS KIVITELEZÉSE
}

\section{DESIGN AND DEVELOPMENT OF COMPUTER- CONTROLLED TEMPERATURE GRADIENT SYSTEM}

\author{
Zakariás Attila, ${ }^{1}$ László Tamás, ${ }^{2}$ Krizbai Csaba, ${ }^{3}$ Szabó Tamás, ${ }^{4}$ Demeter Norbert ${ }^{5}$ \\ Sapientia - Erdélyi Magyar Tudományegyetem, Automatizálás szak, Marosvásárhely, Románia \\ ${ }^{1}$ zakarias.attila@yahoo.com \\ 2 l.tamas04@gmail.com \\ ${ }^{3}$ csaba.krizbai@yahoo.com \\ ${ }^{4}$ sztomi26@yahoo.com \\ ${ }^{5}$ dnorbert@yahoo.com
}

\begin{abstract}
In the XXI. century, the job of a horticulturist is much easier with the help of a thermogradient table, with which you can observe the developmental stage of plants in different temperature conditions, this way, you can find a plant's optimal ambient temperature. The price of a thermogradient table is very high, it can reach thousands of euros. This is the reason why we had the idea to make our own thermogradient table, which is much competitive, and it can ease our institution horticulturist's work..
\end{abstract}

Keywords: thermogradient, optimal seeding, temperature control.

\section{Összefoglalás}

A XXI. században a kertészmérnökök munkáját nagymértékben megkönnyíti egy termo gradiens asztal, amelylyel megfigyelhető a növények fejlődése különböző hőmérsékleteken. Így könnyen meghatározható az egyes növényfajok optimális környezeti hőmérséklete. Egy készen megvásárolható asztal ára nagyon magas, akár több tízezer eurót is elérheti. Innen jött az ötlet, hogy tervezzünk es készítsünk egy saját tervezésű, nagyságrendekkel olcsóbb berendezést, amellyel az intézményünk kertészmérnökök dolgát megkönnyítenénk.

Kulcsszavak: hőgradiens, optimális csiráztatás, hömérséklet szabályozás .

\section{Bevezető}

Célunk megtervezni és megépíteni egy hőgradiens asztalt, melynek lényege az, hogy egy relatív jó hővezető lemez két végét állandó, egymástól különböző hőmérsékleten tartjuk, ennek következtében lineáris hőeloszlást tudunk létrehozni. A rendszer felhasználói, a kertészmérnökök vagy biológusok az asztal felületére növényi magvakat vagy mikroorganizmus telepeket helyezhetnek el, amelyeknek a hőmérsékletet leszámítva azonos körülményeket biztosítunk. [1]. Az esetenként több hetes folyamatot végigkövetve megkapjuk a számukra optimális fejlődési hőmérsékletet.
Az asztal alapjául egy 2000x1000x10 mm méretü, 5083 típusú ( $95 \% \mathrm{Al}, 4,5 \% \mathrm{Mg}, 0,5 \% \mathrm{Mn}$ ) alumínium lemez szolgál. Mivel az alumínium hővezetési tulajdonságait figyelembe véve, a fémek közül jó hővezetőnek számít így megfelel a kívánt fizikai jelenség eredményes kivitelezésére. A hővezetési tényezője $237 \mathrm{~W} / \mathrm{m} \times \mathrm{K}$ és ügyelve arra, hogy minél nagyobb tisztaságú alumíniumot, közelítve a homogén anyag eloszlást, be szerezve sikerül elérnünk a lineáris hőeloszlást. Az alumínium lap egyik végén egy hőforrásként szolgáló fütőellenállás sor egy $\Delta \mathrm{Q}$ hőmennyiséget ad le energia formájában. Mivel tudjuk a termodinamika hőközlés törvényeiből, hogy a leadott hőmennyiség egyen- 
lő a felvett hőmennyiséggel. Így megfogalmazhatjuk, hogy az alumínium lap által felvett hőmenynyiség felírható az alábbi formában:

$$
\Delta Q=m \cdot c \cdot \Delta t
$$

ahol $m$ a lap tömege, $c$ a fajhője míg a $\Delta t$ a hőmérsékletváltozás. A lap másik végén hőelvonóként szolgáló hűtőberendezés által alacsony hőmérsékleten tartott hűtőfolyadékot áramoltatunk rézcsövekben. A hővezetés következtében itt hő vonódik el a laptól, ami egy másik $\Delta Q$, a csövekben egységnyi idő alatt áthaladó hűtőfolyadék tömegével és fajhőjével arányos hőmennyiség. [2].

A 1. ábra bemutatja a lemez hőkamerás felvételét, láthatóvá téve a hideg vég $+2^{\circ} \mathrm{C}$ és a meleg vég $+40^{\circ} \mathrm{C}$-os hőmérsékletét, illetve a lineáris átmenetet. A hőkamerás felvétel az amerikai gyártmányú FLIR One Pro típusú hőkamerával készült. A mérések során igazolódott előzetes feltevésünk, hogy a fémlemez tükröződése megzavarja a kamerát, így a továbbiakban fényelnyelő festékréteggel szándékozunk lefedni.

\section{Szerkezeti megvalósítás}

\subsection{Felépítés}

Az 2. ábra szemlélteti a teljes rendszer tömbvázlatát.

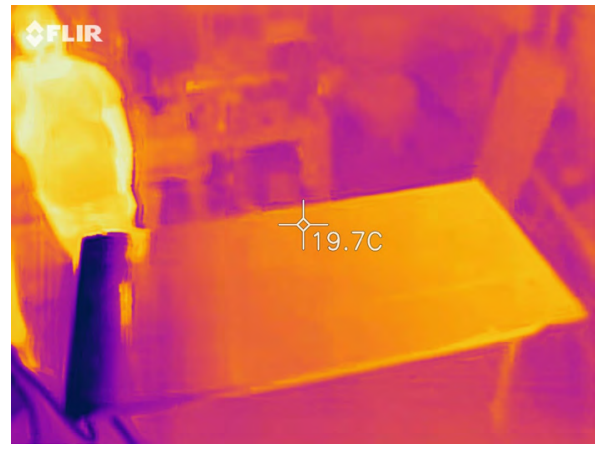

1. ábra. A termogradiens asztal höképe

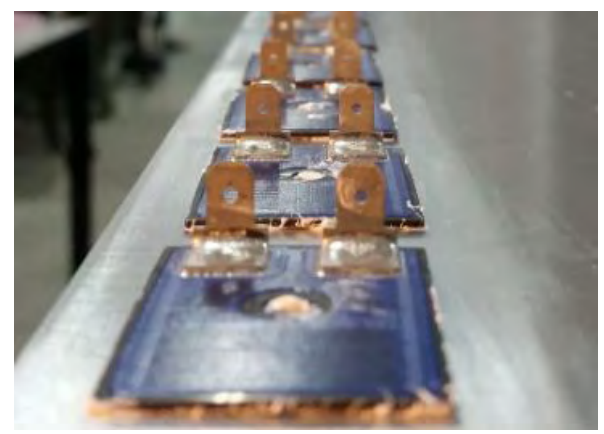

3. ábra. A fütőellenállások illesztése

\subsection{Fütés és hűtés}

$\mathrm{Az}$ asztal meleg végének a fütését 20 darab, egyenként 100W teljesítményü HTS-14 típusú fütőellenállással valósítottuk meg (3. ábra), amit egy saját tervezésű és fejlesztésű fázishasító táp lát el.

A maximális elérhető teljesítmény $2000 \mathrm{~W}$, de a számítások és gyakorlati tesztelések során egyértelművé vált, hogy alacsonyabb teljesítmény értékkel melegíthető a lemez. A táp központi eleme egy PIC típusú mikrovezérlő, ami a 230V feszültségű hálózati váltóáram fázishasítását vezérli egy triak segítségével.

A hűtést egy 12000 BTU hűtőteljesítményű Beko márkájú BPEU121 típusú légkondicionáló rendszer felhasználásával valósítottuk meg. A légkondicionáló beltéri egységét szétbontottuk és a hőcserélőt beépítettük egy hűtőfolyadékkal feltöltött tartályba, amely körülbelül 33 liter menynyiségű etilén glikol fagyállóval van feltöltve. A fagyálló hűtőközeg keringetését egy DAB Evotron 60/130 típusú keringető szivattyúval valósítottuk meg. A hideg végre egy réz hőcserélőt illesztettünk (4. ábra). [3]

\subsection{Hőmérséklet mérés}

A hőegyensúly tranziens és végső állapotát egy mikrovezérlő alapú szenzorrendszerrel és egy

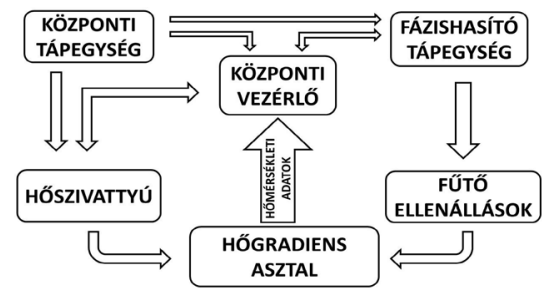

2. ábra. A rendszer tömbvázlata

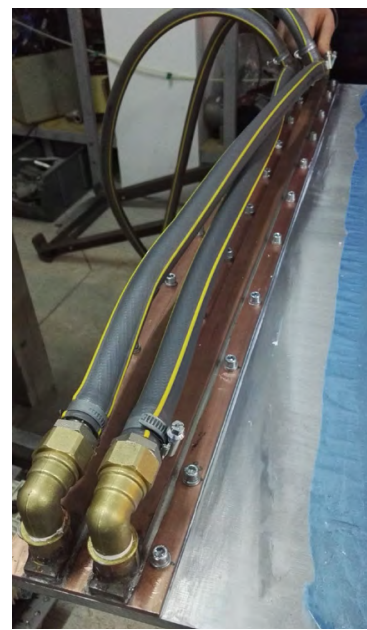

4. ábra. Hőcserélő lemez felszerelve az alumínium tömb aljára 
Flir One Pro típusú hőkamerával mérjük és vizualizáljuk. A hőmérő rendszert egy Arduino Nano és tíz darab DS18B20 típusú, OneWire tehnológiájú digitális szenzor alkotja. Az Arduinóra megírt program tíz különböző ponton méri előre megadott időközönként a hőmérsékletet, elküldi egy számítógépre, amelyen egy CVI Labwindows fejlesztőkörnyezetben megírt software grafikusan megjeleníti, valamint állományba tárolja a mért adatokat. [4]

\subsection{Fázishasító tápegység}

A fázishasító tápegység áramköri rajzát, majd a nyáktervét egy Eagle nevezetű szoftver segítségével terveztük meg. A tervezés után elkészítettük, fototechnikai módszerekkel a nyákot és beültettük az alkatrészeket. A táp alapjául egy PIC 16f684 típusú mikrovezérlő szolgált, ami egy 0-5V tartományban kapott vezérlő analóg jel, és a hálózati szinuszos feszültség nullátmenetei alapján, előállít, megfelelő időközönként, egy PWM (impulzus szélesség modulált) jelt, ami egy optocsatoló segítségével gyújtó impulzusokat állít elő egy triacnak, ami elvégzi a fázishasítást. A következő képeken néhány oszcilogramm látható a tápról miközben dolgozik. A 5. ábrán az oszciloszkóp egyes csatornájára az analóg vezérlő feszültség volt bekötve, a kettes csatornára a PIC vezérlő által generált gyújtóimpulzus. [5]

$\mathrm{Az}$ 6. ábrán a fázishasított hálozati feszültség látható, a fütőellenállás kapcsain mérve.

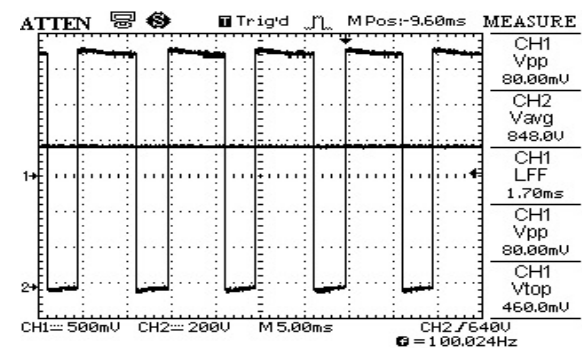

5. ábra. A vezérlő analog jel és a gyújtóimpulzus

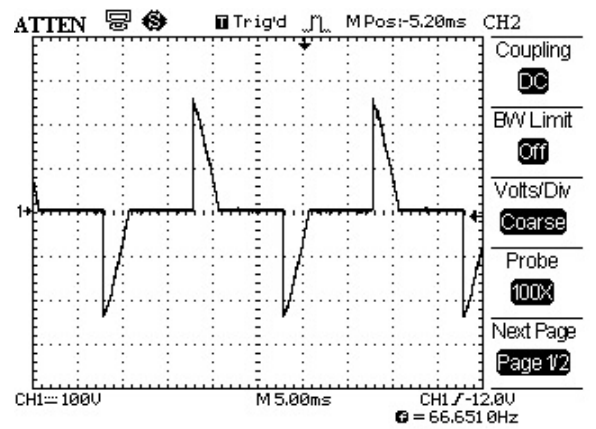

6. ábra. A fázishasított szinusz jel
Ilyen módon, ha mérjük a hőmérsékletet a gradiens asztal meleg pontján, akkor szabályozni is tudjuk azt, így beállítva a kívánt hőmérsékletet.

A PIC mikrovezérlőre mikroC PRO for PIC programban fejlesztettünk egy firmwaret, ami kezeli a fázishasítást, és egy hűtőventilátort ami a triacra szerelt hűtőbordáról vonja el a termelt hőt, ha szükséges.

\section{Számítások, szimuláció, mérések}

\subsection{Számítások}

$\mathrm{Az}$ alumínium lap fütése és hütése következtében létrejövő hőterjedést matematikai modell segítségével is felírhatjuk. A differenciál-egyenlet felírásához két fizikai alapegyenletet veszünk alapul. Az egyik, hogy a hő a magasabb hőmérsékletű helyről az alacsonyabb felé áramlik. A másik pedig Joseph Fourier törvénye, amely szerint a hőáramlás sebessége arányos a hőmérséklet adott irányú deriváltjával. Ha figyelembe vesszük a peremfeltételeket, az alumínium lap két végén, a hőforrás és hőelvonó jelenlétét és a kezdeti hőmérsékletet, felírható egy kétváltozós differenciálegyenlet,

$$
f=\frac{d u}{d t}-\frac{a \cdot d^{2} u}{d x^{2}}
$$

amely így a hővezetési egyenletre vonatkozó vegyes feladatot értelmezi és amely segítségével kiszámolhatjuk egy adott pont hőmérsékletét egy adott időben. A kettes egyenletben az a konstans

$$
a=\frac{k}{c \cdot g}
$$

ahol $k$ hővezetési tényező, $c$ az alumínium tömbfajhője, míg $a$ az alumínium sűrüsége.

\subsection{Szimuláció}

A fenti egyenlet mellett ENERGY 2D-ben szimulációval is bebizonyítottuk a lineáris hőeloszlás létrejöttét. Az alábbi ábrákon látható szimulációban szemléltetve van az alumíniumban létrejött hőeloszlás. Figyelembe véve az alumínium és a szigetelőanyag fizikai hőáteresztő tulajdonságait igazolható a szimuláció lejártával a hőeloszlás. (7. és 8. ábra)

\subsection{Mérések}

Miután meggyőződtünk, hogy a szimuláció is igazolja számításainkat, és elkészültek a termogradiens asztal tartozékai, elindítottunk egy próba mérést, a szenzorrendszer segítségével. A mérés 
lezajlása után, és az adatokat ábrázolva grafikon formájában, véglegesen beigazolódtak a feltevéseink. Az alumínium lemezen szép egyenletesen oszlik el a hő. $40{ }^{\circ} \mathrm{C}$-tól egészen $3{ }^{\circ} \mathrm{C}$-ig. A következő grafikonon (9. ábra) a mérési eredmények láthatóak.

A mérés egy óra időtartamot tartalmaz, a programot 10s-os mintavételezésre állítottuk be, ez megközelítőleg 300 mintát jelent. Látható, hogy a hőmérsékleteloszlás közel egyenletes.

\section{Következtetések, jövőbeli tervek}

A cikkben bemutatott hőgradiens rendszer megépítésének szükségessége a Sapientia EMTE Marosvásárhelyi Karának Kertészmérnöki Tanszékének oktatóival és diákjaikkal való elmélkedések alapján fogalmazódott meg. Látva a rendszer fokozott és azonnali alkalmazhatóságát, II. éves villamosmérnöki hallgatóként vállaltuk e munkát, aminek során gyakran ütközünk még nem tanult fogalmakban és technológiákban. Kihívásként fogjuk fel ezeket az akadályokat és feltett szándékunk, hogy a további diákkutatói tevékenységünk

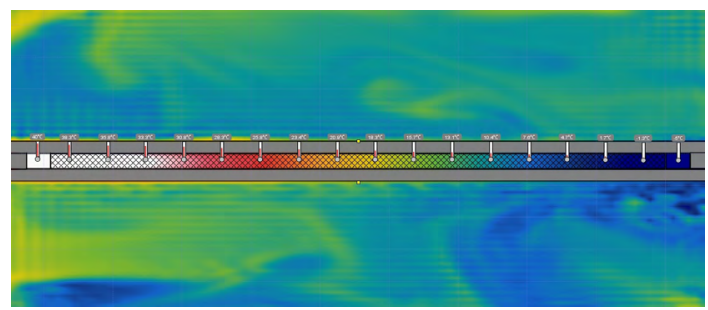

7. ábra. Höeloszlás az alumínium tömbben

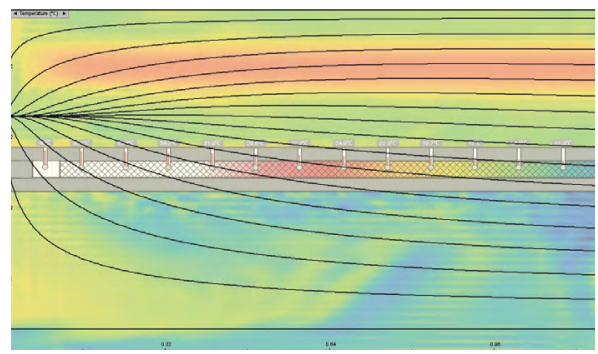

8. ábra. A hőmérsékletváltozás különböző pontokban

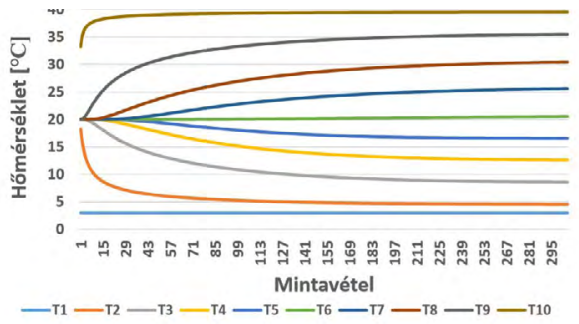

9. ábra. A mérési grafikon végén egy jól működő automata rendszert adjunk használatra a kertész és biológus kollégáknak.

A továbbiakban szeretnénk tanulmányozni a hőszivattyú kommunikációs vonalát, hogy azt vezérelve, kitudjuk alakítani az optimális hőegyensúlyt. Be fogunk építeni mindent alkotó elemet az asztalba, hogy az átlagfelhasználók által is könynyedén kezelhető legyen. Speciális növényeknek megfelelő, állandó fényt kibocsájtó világításrendszerrel szándékszunk ellátni a rendszert, hogy beltéri használatra is alkalmas legyen. Továbbá tervünk, egy interaktív kezelőfelület létrehozása, amelyen egyszerủen beállíthatók a paraméterek, valamint visszajelzést kapunk a hőmérséklet illetve páratartalom értékekről. Szükségesnek látjuk hőszigetelni a lemezt illetve kialakítani egy zárt tért, hogy relatív kevés energia felhasználásával tudjuk állandó hőmérsékleten tartani a kísérlethez használt biológiai anyagot. Nem utolsó sorban olyan külsőt tervezni, hogy az általunk tervezett rendszer akár piacképes is legyen.

\section{Köszönetnyilvánítás}

E kutatási tevékenység eredményei nem jöhetettek volna létre az NTP-FKT-17 rendszerben elnyert pályázat “Tehetséges műszaki és mezőgazdasági mérnök hallgatók interdiszciplináris kutatásainak támogatása” címü program hathatós támogatása nélkül. A szerzők továbbá köszönik Szőllősi István technikus úrnak és dr. Jakab-Farkas László tanár úrnak a hasznos tanácsokat és segítséget.

\section{Szakirodalmi hivatkozások}

[1] Grey T., Chen Y. Ch., Nuti R., Monfort W. S.: Advances in Seed Biology. Characterization of Genotype by Planting Date Effects on Runner-Type Peanut Seed Germination and Vigor Response to Temperature. 1. kiadás. Intech, London, 2017. 103-120.

[2] Grant Instruments UK, Scientific Report.

https://www.grantinstruments.com/scientific/ temperature-gradient-plate-seed-germination-efficacy-testing (letöltve: 2018. szeptember 11.).

[3] Price D. T., Leadem C. L.: A computerized, solid-state, controlled temperature gradient system for determining optimal seed germination temperatures. In: Dormancy and barriers to germination. Victoria, Canada, 1991. 103-112.

[4] Liu Z. J.: Multi Point Temperature Measurement System Based on DS18B20. Advanced Materials Research 756-759. (2013) 556-559.

https://doi.org/10.4028/www.scientific.net/ AMR.756-759.556

[5] Microchip Appnote US, AN958 Appnote, 2004. http://www.microchip.com/downloads/en/appnotes 00958a.pdf (letöltve: 2018. november 10.). 